\section{El programa arquitectónico en las bases de un concurso}

Claudio Vásquez Profesor, Escuela de Arquitectura, Pontificia Universidad Católica de Chile

El programa arquitectónico es el instrumento esencial con que cuentan las bases de un concurso. El programa es la prefiguración de la forma y en él se esconde el fondo del problema. Su elaboración conceptual se nutre de la información que entrega el mandante, que da forma a los sistemas y componentes del cálculo lógico que debe ser llevado a la realidad.

Un concurso de arquitectura ${ }^{1}$ es tanto un despliegue de competencias profesionales como la concurrencia de sucesos que encarnan una escena donde mandante, jurado y concursantes pueden asumir papeles diversos. Es también planear y seguir un curso, un camino establecido a través de unas bases que se formulan como campo de trabajo o escenario, dando una dirección determinada o libertad de movimiento al desarrollo de la escena. Los concursantes pueden seguir sus indicaciones o no hacerlo, a riesgo de quedar fuera de la trama.

Cuando OMA cambió el lugar propuesto por las bases del concurso del Centro de Congresos de Córdoba, en España el 2001, confirmó que la actitud de seguir un curso autónomo tiene cabida si se interpreta correctamente el problema del mandante. Compitiendo con Cruz y Ortiz, Zaha Hadid, Toyo Ito y Rafael Moneo, Koolhaas renegó del sitio rectangular dispuesto a espaldas del Centro Histórico de la ciudad en la península de Miraflores, sobre el Guadalquivir, para disponer un volumen lineal activamente vinculado a dicho foco monumental. La operación liberó el terreno original vinculando el Centro de Congresos visualmente con la Mezquita de Córdoba, desde el parque Miraflores. ...iTouché!...

Una acertada interpretación del problema del mandante abrió un camino paralelo, fuera de las bases, aunque posible y verosímil como opción. Fernández-Galiano (2001) calificó la propuesta como brillante y arriesgada, sin embargo, el carácter privado del concurso y la categoría de sus invitados permitían aceptar este tipo de escenas inesperadas. En parte era esto lo que el Ayuntamiento de Córdoba buscaba invitando a quienes fueron los participantes. La defensa gremial implícita en el comentario de FernándezGaliano, calificando de genial el riesgo asumido por Koolhaas, es similar a las múltiples voces que se levantaron en 1927 defendiendo la propuesta de Le Corbusier y Pierre Jeanneret para el Palacio de las Naciones en Ginebra.

Para este concurso un total de 377 oficinas de arquitectura de diferentes partes del mundo completaron más de $10 \mathrm{~km}$ de planos donde pudo ser apreciada una variopinta cantidad de opciones adscritas o basadas en diferentes postulados arquitectónicos en pugna en ese momento. El jurado estaba compuesto por diez miembros representantes de distintos países y entre ellos había connotados arquitectos de la época como Berlage, Hoffmann, Moser, Horta y Lamaresquier (Zervos, 1993). En 64 sesiones fueron seleccionados nueve primeros lugares, sin embargo se filtró a la prensa la insólita situación que le quitó al proyecto de Le Corbusier y Pierre Jeanneret la victoria solitaria: sus planos habían sido reproducidos mecánicamente, a pesar de que las bases prohibían explícitamente el uso de moyens mécaniques. Con este argumento los miembros del jurado detractores de la arquitectura moderna lograron diluir la decisión. Esta escena fue más dificil de aceptar por Le Corbusier y Pierre Jeanneret al confirmar que su propuesta era la única que cumplía de forma estricta, con el presupuesto de construcción establecido como tope, el resto de los seleccionados lo superaban onero-

\section{The architectural program in competition rules}

The architectural program is the essential instrument available for formulating competition rules. The program is the prefiguration of the form, and reveals the essence of the architectural problem. Its conceptual development is based on the information supplied by the commissioning entity, which shapes the systems and components of the logical calculus called for.

Architecture competitions ${ }^{1}$ are at the same time a deployment of professional skills and a confluence of events that create a scene in which a commissioning entity, a jury and competitors assume distinct roles. This requires planning and following a course of action defined by rules that create a playing field or stage, impart a particular direction to the scene, or allow latitude in the way the scene unfolds. Competitors can choose to follow guidelines, or can interpret them less than literally-though in doing the latter they risk losing their place in the cast of eligible players.

In 2001, when OMA changed the location for Córdoba's Centro de Congresos, in Spain, it demonstrated that there is a place for autonomous decision-making in such contexts, provided that the challenge posed by the commissioning entity is interpreted with understanding. Competing with Cruz y Ortiz, Zaha Hadid, Toyo Ito and Rafael Moneo, Koolhaas rejected the rectangular site behind the city's historic center on the Guadalquivir's Miraflores Peninsula, instead proposing a linear volume actively linked to that focus of interest as a monument. The reinterpretation freed itself from the original piece of land, visually linking the Centro de Congresos with the Córdoba Mosque from the viewpoint of Miraflores Park. ...iTouché!...

Thus, an insightful interpretation of the problem posed led to a path that lay outside of the guidelines, but was parallel to them, and constituted a plausible option. Given the private nature of the competition and the class of architects invited to submit proposals, it was possible to make room in the competitive scenario for that unexpected proposal, which FernándezGaliano (2001) described as brilliant and daring. In a sense, the proposal represented what Córdoba's municipal government was after in selecting the participants that it did. The collegial defense implicit in Fernández-Galiano's description of Koolhaas's risk as a stroke of genius recalls the voices that were raised in defense of Le Corbusier's and Pierre Jeanneret's proposal for the Palace of Nations in Ginebra in 1927

In that competition, a total of 377 architectural firms from around the world created over $10 \mathrm{~km}$ of architectural plans, and a plethora of options associated with and based on various polemical architectural issues of the moment. The jury consisted of ten members from different countries, including well-known architects of the time such as Berlage, Hoffmann, Moser, Horta and Lamaresquier (Zervos, 1993). The jury met 64 times, and chose nine winners instead of one. The press got wind of the surprising fact that Le Corbusier and Pierre Jeanneret had been deprived of an unalloyed victory because their plans had been mechanically reproduced, in violation of the rules, which explicitly prohibited the use of moyens mécaniques. The jury's anti-Modernist members had succeeded in diluting the victory by distributing it among various competitors. The decision proved particularly hard for Le Corbusier and Pierre Jeanneret to swallow when they learned that their proposal was the only one that strictly met the proposed construction budget, while the other winning plans stretched the budget to 
1 Entendemos como concurso de arquitectura aquellos concursos que tienen como objetivo la construcción de una obra por considerar que son los únicos que, estrictamente, valga la redundancia, son de arquitectura. Los concursos teóricos que se sabe que no serán construidos, los concursos come ciales de promoción de materiales, ciales de pros cocion de materiales, aquellos que buscan promocion actividad académica en torno a temas específicos, y en general, cualquier otro tipo de certamen que busca premiar aspectos parciales de proyectos, no son objeto del contenido de este texto.

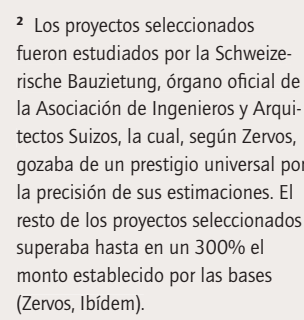

\section{Para José Ricardo Morales la radical singularidad de la arquitec- tura llega al punto de considerar necesario preguntarse cómo la arquitectura reobra sobre el hombre es decir, cómo lo afecta y genera un proceso de acción y coacción entre ambos (Morales, 1969).}

samente $^{2}$. Una comisión especial fue designada para terminar el trabajo inconcluso del jurado, la cual para salvar el problema y tener una definición rápida del ganador, gestionó el aumento del presupuesto en un 50\%, contrariando toda expectativa ética en el concurso. Finalmente el primer lugar fue otorgado al proyecto de Henri-Paul Nénot y Julien Flegenheimer, representantes de Francia entre los seleccionados.

En este caso la escena tuvo como protagonista al jurado, no a los concursantes, ya que se transformó en un problema central la estricta e irreflexiva aplicación de las bases para algunas cuestiones y su omisión para otras. Le Corbusier y Pierre Jeanneret cumplieron en los aspectos más profesionales y difíciles del encargo, como fue el presupuesto. Sin embargo, por truculentas situaciones internas de la deliberación, fueron despojados del contrato de construcción. Como consuelo, Le Corbusier dejó plasmada su iracunda reacción a través de la publicación de su libro Une maison - un palais, que nos ha quedado como legado del certamen.

Las escenas que puede detonar la relación entre concursantes, jurado y mandante son diversas, sin embargo hay una condición intrínseca y determinante en su configuración: las bases funcionan como campo de trabajo o escenario, ellas detonan la trama de acontecimientos que se desencadena ya sea por acción o por omisión, es decir por lo que dicen o dejan de decir. ¿Qué son entonces las bases de un concurso de arquitectura? Esencialmente, son el instrumento a través del cual se prefigura un encargo, estableciendo parámetros que deben ser connaturales a la forma, lo cual no es fácil, y con dificultad podría ser hecho por un lego en la disciplina. En efecto, un mandante pocas veces cuenta con el bagaje necesario para llevar sus requerimientos a códigos de prefiguración en el sentido que hablamos, sin embargo, probablemente, desde su perspectiva puede tener claro lo que necesita.

Esta situación es normal y se puede entender a partir de una de las características de la arquitectura entendida como arte que expone José Ricardo Morales. Para él la arquitectura es diferente al resto de las artes en que “... representa -y da lugar a- nuestras necesidades ineludibles..." ${ }^{3}$, por lo tanto afecta a todos los hombres, en cambio, las otras artes responden a intereses o gustos singulares, es decir, tienen público y cultores especiales porque sus obras no coaccionan con el hombre, no lo afectan en su cotidianidad. Este aspecto de la arquitectura permite entender que un mandante pueda saber con claridad lo que necesita, puesto que sabe cuáles son sus necesidades ineludibles, sin embargo esto no es suficiente.

El centro del problema de un encargo de arquitectura está en el sentido que tiene el programa arquitectónico en la prefiguración de la forma, ya que en su formulación se esconde el germen del proyecto. Este es el instrumento esencial con que cuentan las bases y en su elaboración resulta ineludible un estudio especializado y detallado de los requerimientos del mandante para caracterizarlos dentro del universo de instituciones, programas o edificios al que pertenece su encargo.

\section{Architectural competition in our cesigned to culninate in cotions ion, such competitions being the only ones strictly architectural in nature from our point of view. Not included, then, are theoretical com- petitions for designs that there is no intention of building, commercial competitions organized to promote materials, competitions designed to promote academic activity around particular issues or subjects, and competitions that award prizes for specific, partial aspects of architec- tural projects.}

${ }^{3}$ In the view of José Ricardo Morales, the radical singularity of architecture points ing the question of how architecture the question of how architecture reshapes man, i.e., how it affects the human being and generates process of action and compulsion between the two (Morales, 1969). 
4 Ibídem.

5 lbídem.

6 Este estudio fue realizado por

autor en conjunto con los arqui-

tectos Fernando García-Huidobro

Diego Torres y Fabián Todorovic.

El sentido instrumental y determinante del programa como prefigurador de la forma fue claramente expuesto por Isidro Suárez (1985) cuando lo definió como entelequia del proyecto, es decir, como problema central y objetivo de la actividad de proyectar o llevar un requerimiento a la forma. Para él, el proyecto podía ser entendido como un modelo de la realidad, y como tal, era una realidad interpuesta que representa otra, que no es el propio proyecto, sino su potencial existencia en el mundo construido. Esta relación con la realidad es entonces doble: la realidad del proyecto, o de la planta sometida a sus propias normas, y la realidad de la realidad, que está referida al fenómeno histórico de los usos y costumbres con los que el proyecto debe encajar, es decir a lo que el mandante conoce por ser sus necesidades ineludibles. En otras palabras, hay normas implícitas del proyecto que apuntan a su inserción en la vida cotidiana recogiendo los usos que debe contener, y en forma paralela, la misma planta debe contener coherencias internas propias que la estructuran como una forma arquitectónica que debe ser coherente en sí misma.

El programa entonces adquiere dos frentes: uno cultural referido a los usos y que se podría resumir en una lista de recintos, y otro que apunta al trabajo pre-composicional para la formulación conceptual del partido general de los proyectos que se busca comparar para seleccionar un ganador.

Ciertamente las bases de un concurso pueden omitir una lista de recintos exigiendo a los concursantes resolverlo como parte del encargo, sin embargo no pueden omitir los datos que permitan realizar el estudio pertinente para elaborar ambos aspectos del programa, lo cual resulta extremadamente difícil debido a que en el régimen de funcionamiento de un concurso los participantes no tienen acceso al mandante funcionando como contraparte. Los llamados de este tipo corren un alto riesgo de ser declarados desiertos, simplemente por ser inciertos.

Isidro Suárez entregó además herramientas metodológicas que permiten enfrentar el estudio de un programa:

"En primer lugar, el (programa) nos aparece como una petición para la constitución del proyecto. En segundo lugar, esta constitución del proyecto, para serlo, debe ser un estudio. En tercer lugar, este estudio comporta básicamente un análisis que recoge en diversos sistemas lógicos los constituyentes" ${ }^{4}$.

Interrumpimos para remarcar la idea de que el programa es un estudio, no una enumeración. Esta es la primera segmentación en que se puede dividir el universo de bases de concurso: aquellas que tienen detrás un estudio y aquellas que sólo tienen una enumeración de recintos. Las primeras tienen una alta probabilidad de éxito si el resultado del estudio es conducente a una forma y las segundas con facilidad pueden terminar con primeros lugares desiertos o con premiaciones exóticas.

Seguimos atendiendo al planteamiento de Isidro Suárez:

"El programa, en cuanto cálculo lógico como sistema, se compone de la enumeración de exigencias, que es el alfabeto, las condiciones a cumplir, que son las reglas de formación, y las conexiones entre estas condiciones, que serían las reglas de transformación. Como se sabe alfabeto, reglas de formación, reglas de transformación son los tres elementos que constituyen el cálculo lógico como sistema, y se definen así: alfabeto conjunto de símbolos elementales; reglas de formación que indican cómo pueden combinarse los símbolos elementales en formaciones compuestas; reglas de transformación que indican cómo puede pasarse de una combinación de símbolos a otra combinación o sea de una forma lógica a otra, lo que equivale a transformar la primera"

Para cualquier arquitecto es evidente que el programa y su organización suponen una labor conceptual que se nutre de información que entrega el mandante en un proceso casi terapéutico de conversación, cuyo objetivo es encontrar directrices y lógicas de relaciones a las cuales normalmente no se llega de forma directa. El texto citado propone descomponer este proceso en tres partes que se transforman en factores para realizar un cálculo lógico. Ellos son: una enumeración, que es aquello que el cliente sabría con propiedad; unas reglas de formación, que son las normas o condiciones a las que debe estar sometido cada elemento de la enumeración; y unas reglas de transformación, que imponen las normas de relación entre ellos.

Isidro Suárez ahondó en la cuestión del programa explicando que estos componentes y relaciones no tienen sentido alguno por sí solos, ya que debe ser formulado un teorema que permita llevar los sistemas y componentes del cálculo lógico a la realidad, en su doble acepción antes descrita. En otras palabras, uno o varios arquitectos deben dar forma al programa, siendo este su rol al participar en un concurso de arquitectura. En efecto, los tres factores componentes del cálculo lógico constituyen instrumentos de proyecto que permiten a distintos arquitectos formular soluciones con la misma matriz conceptual, desplegando cada uno sus competencias profesionales como conformadores, o dadores de forma, de un programa.

El encargado de la redacción de las bases es normalmente el director del concurso, quien tiene la tarea de conducir el trabajo de los concursantes a través de la especificación del conjunto de factores que permitan la prefiguración de sus propuestas. En este trabajo es relevante el diseño de la entrega de planos y maquetas, que debe ser ajustada a la mínima necesaria para medir la adecuación de los proyectos al programa y su cálculo lógico. De esta manera se transforma en una figura alejada del mero rol administrativo que supone la organización y la redacción de documentos.

Para entender más claramente, un ejemplo: el año 2005 una congregación religiosa llamó a concurso para la creación de un nuevo colegio. El problema era complejo ya que suponía operaciones de diversa índole para lo cual fueron formadas distintas mesas de trabajo, una de las cuales se dedicaría a la infraestructura. Fui invitado a ella por anteriores experiencias en la formulación de programas arquitectónicos asociados a proyectos educativos ${ }^{6}$

El estudio del programa partió con el análisis de casos que por distintas aproximaciones eran comparables con el nuevo colegio, ya sea por sus proyectos educativos, por las características de sus sostenedores, alumnos y familias, o por sus condiciones urbanas. Este estudio permitió establecer los estándares espaciales dentro de los cuales el proyecto debía situarse, es decir, hizo comparable el servicio que proponía brindar el nuevo colegio. En paralelo, fue realizada una ardua labor de cualificación espacial del proyecto educativo de la nueva institución, definiendo la enumeración de recintos y sus reglas de formación a partir de aquello que el mandante conocía como sus necesidades ineludibles. Este estudio entregó una lista de recintos cuyos tamaños debían ser establecidos comparativamente con 
4 Idem.

5 Idem.

6 This study was conducted by the

author with architects Fernando

García Huidobro, Diego Torres and

Fabián Todorovic.

The instrumental and determining character of the architectural program as a prefiguration of architectural form was clearly expressed by Isidro Suárez (1985), who called it as the project's entelechy, i.e., the central problem and objective of the activity of projecting or translating needs into architectural forms. In his view, architectural designs can be understood as a model of the architectural reality. Thus, a design is an interposed reality that represents another reality the latter being not the design, but its potential existence as constructed reality. The reality relationship is thus a double one. One aspect of it is the reality of the design, or the plan in its own terms, while the other is the reality of the reality, which is linked with the historical uses and customs into which the design is to fit i.e., those factors that the commissioning entity has identified as irreducible needs. In other words, the design has implicit parameters that shape it for everyday life by designing it for specific uses, while, at the same time, it must have an internal consistency that gives it a coherent architectural form on its own terms.

Thus, a competition must be structured with two aspects of the architectural work in mind: a cultural, use-defined aspect, which may be represented by a list of physical spaces, and an aspect that reflects the pre-compositional work involved in the conceptual formulation of the designs that are to be compared to select a winner.

Clearly, the rules of a competition may omit a list of physical spaces, and leave this to the competitors. The data involved in conducting the study needed to address both aspects must be provided, however. This is extremely difficult, since under the rules of the game, participants in a competition are unable to dialogue with the commissioning entity. Affected by these constraints, competitions run a risk of having to declare no winner, simply because of the uncertainty involved.

Isidro Suárez also provided methodological tools that facilitate the study needed for the program behind the rules of a competition:

"In the first place, the (program) seems to us a request for the creation of the design. Secondly, if this creation of the design is to be serious, it must take the form of a study. Thirdly, the study basically consists of an analysis that considers the constituent elements from the point of view of various logical systems"4.

Let us note parenthetically that the program is a study, not an enumeration. This is the first distinction that divides the universe of competitions: those whose rules are based on a prior study, and those that are simply an enumeration of spaces. The former have a high probability of success if the result of the study is conducive to architectural form, while the latter may easily end with no winner or with results outside of normal parameters.

To return to Isidro Suárez, we see that:

"The program, as a logical calculus functioning as a system, is composed of an enumeration of needs, the alphabet and the conditions to be met, which in turn are the formational rules and the connections among these conditions, i.e., the transformational rules. As we know, an alphabet, formational rules and transformational rules are the three elements constituting a logical calculus as a system, and are defined as: an alphabet consisting of a set of elementary symbols, formational rules that govern how these can be combined to create composite forms, and transformational rules that govern transformations from one combination of symbols to another, i.e., from one logical form to another, which is equivalent to transforming the logical form"s.
It is clear to any architect that the program and the organization of the program require conceptual work that is fueled by information obtained from the commissioning entity in a conversational process that is quasi-therapeutic in nature, the objective of which is to define guidelines and relational logics that are ordinarily not arrived at directly. Suárez divides this process into three parts, which become factors in carrying out a logical calculus-namely, an enumeration (which is what the client would know from his own thinking and experience), formational rules (the standards or conditions to which each enumerated element is to be subject) and transformational rules that govern the interrelations between these elements.

Isidro Suárez went deeper into the question of the architectural program, explaining that these components and relationships are not meaningful in themselves. Rather, a theorem must be formulated that makes it possible to translate the systems and components of the logical calculus into reality, in the double sense mentioned above. In other words, one or a number of architects must give the program form, and this is their role as participants in an architectural competition. In effect, the three components of the logical calculus are instruments of the project that permit different architects to formulate solutions within the same conceptual matrix, deploying their professional skills as factors shaping or imparting form to a program.

The director of a competition is normally responsible for writing the rules, as well as directing the competitors' work by specifying the set of factors that govern the preliminary formation of their proposals. Organizing the delivery of plans and architectural models is a part of this work, and must consider the criteria for measuring the degree to which the projects meet the requirements of the program and its logical calculus. It thus goes beyond the merely administrative role of organizing and writing documents.

An example may help to make this clear. In 2005, a religious congregation announced a competition to create a new school. The problem was a complex one, since operations of various types were involved. Different working groups were formed to address them. One was devoted to the subject of infrastructure, and I was invited to participate in it because of my previous experience in formulating architectural programs associated with educational projects ${ }^{6}$.

The study began by analyzing cases comparable to the proposed school from various points of view, either educationally, because of the nature of their funders/entrepreneurs, students and families, or as a function of their urban settings. The study produced the spatial parameters within which the project was to be situated, i.e., furnished a framework for the services that the new school was to provide. Meanwhile, the arduous work of describing the new institution's educational activity in spatial terms took the form of enumerating physical spaces and their formational rules, based on what the commissioning entity had identified as irreducible needs. The study provided a list of areas the sizes of which were to be established in comparison with the characteristics of the case studies initially examined. 


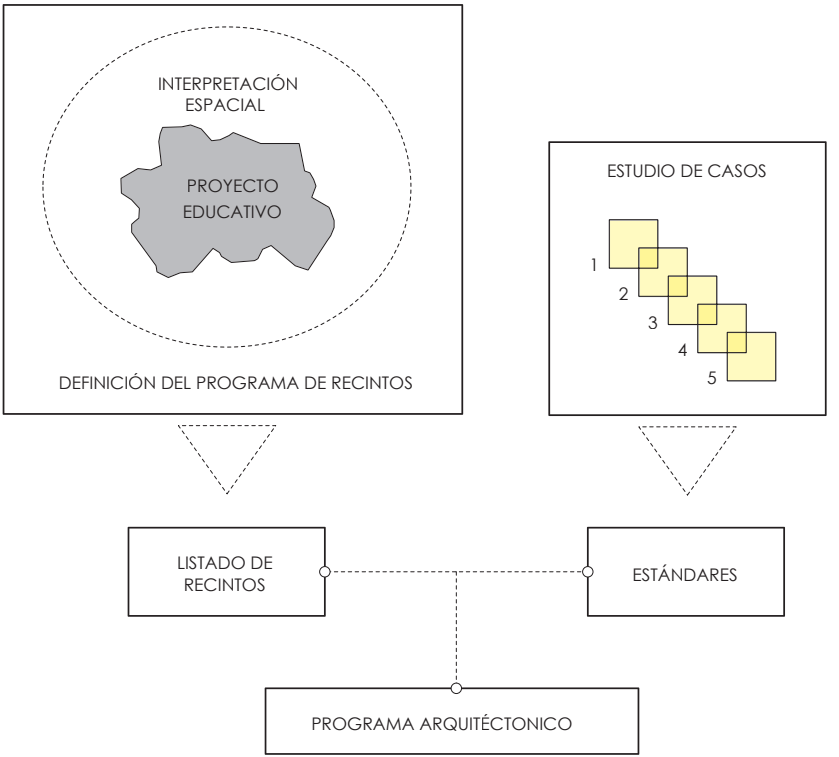

01

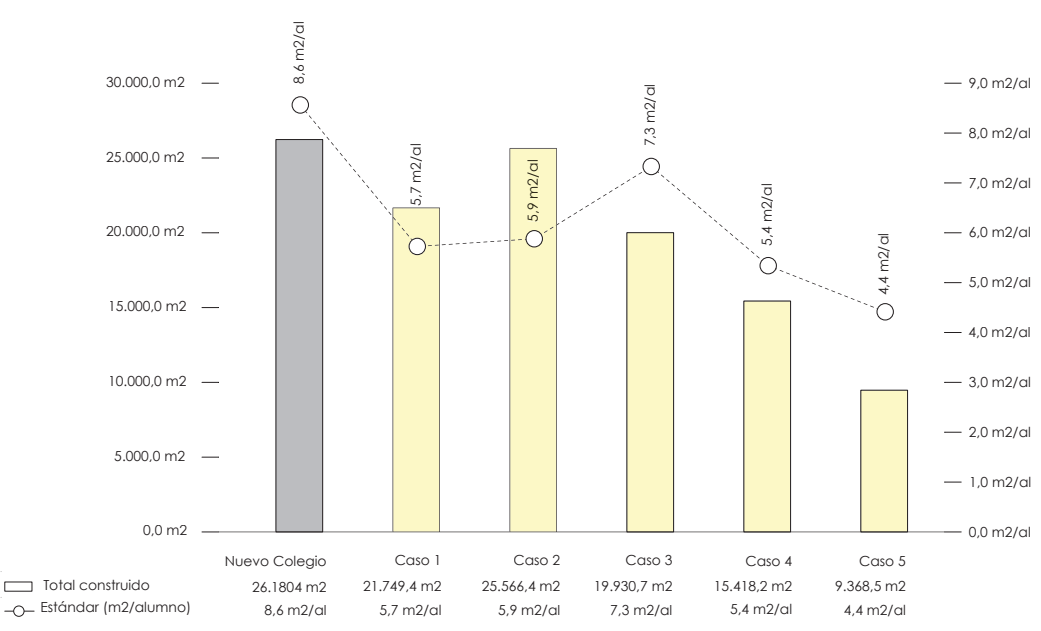

02

01 Esquema metodológico para la construcción del programa arquitectónico.

02 Gráfico de la superficie construida y los estándares $\mathrm{m}^{2}$ / alumnos del nuevo colegio en comparación con los

casos de estudio. Este gráfico muestra que, en un momento, el estándar fue mayor al de las referencias, sin embargo el objetivo era superarlas en algunos aspectos manteniendo el total en un tamaño relativamente similar a ellas. Con este resultado fue necesario realizar ajustes.

03 Reglas de transformación del programa del nuevo colegio. Esquema Fabián Todorovic.

04 Esquemas de algunos anteproyectos entregados en el concurso. La comparación muestra la correspondencia de

ellos con las reglas de transformación de la figura 3. Esquema Fabián Todorovic.

01 Methodological scheme of the architectural program.

02 Graph of area built on for the new school and the ratio of area to number of students, in comparison with case studies. As the graph shows, the ratio exceeded guidelines, but in fact the objective was to exceed them in some ways, without greatly modifying total size. Adjustments did have to be made to this scheme.

03 Transformational rules of the program for the new school. Scheme by Fabián Todorovic.

04 Schemes for some of the competitions proposals. Comparison shows how they correspond with the transformational rules in figure 3. Scheme by Fabián Todorovic.

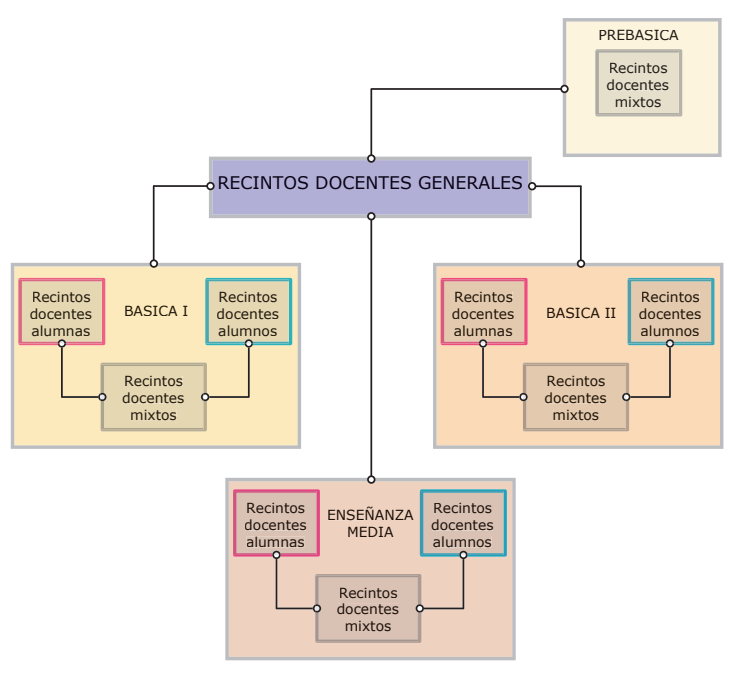

03

COLEGIO DE EDUCACIÓN COMPARTIDA
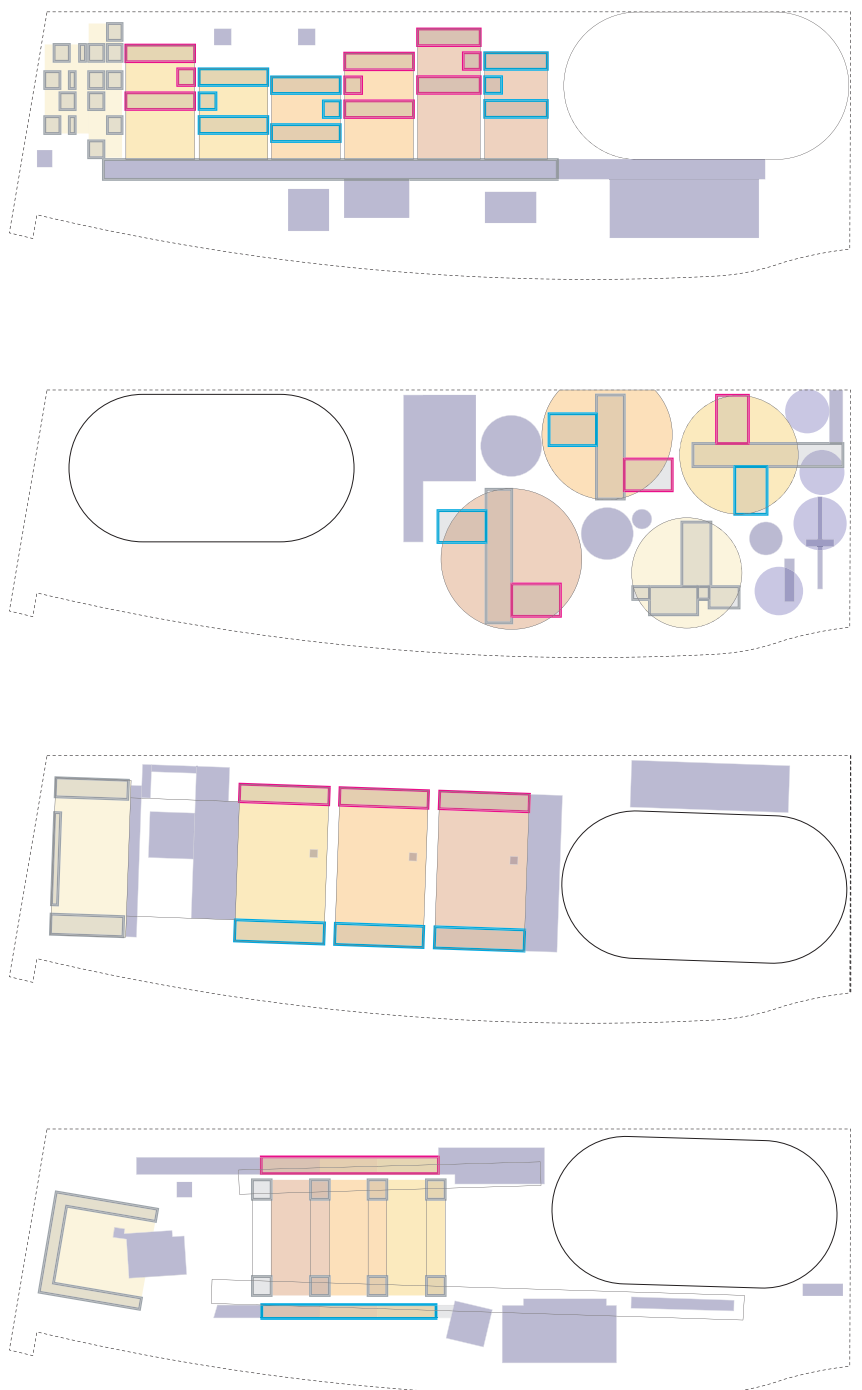
el estudio de casos. El esquema representa sintéticamente este método de trabajo (fig. 1).

El resultado permitió establecer precisiones como el estándar $\mathrm{m}^{2} /$ alumno que el nuevo colegio tendría en relación a la superficie construida, en comparación a los casos seleccionados como referencia. El gráfico (fig. 2) muestra una de las primeras aproximaciones que permitió conocer con anticipación que la enumeración de recintos por sí sola hubiera sobredimensionado el estándar espacial del nuevo colegio, debiendo ser reformulada. Este ejercicio se realizó para la definición de distintos componentes del programa, como los recintos destinados a docencia formal, los patios, la infraestructura deportiva o aquellos recintos que podían ser entendidos como característicos del proyecto educativo de cada caso. Una lista de recintos y sus tamaños adecuados son la enumeración y parte de sus reglas de formación, ya que, asociados a sus dimensiones, están los requerimientos técnicos que deben cumplir, es decir, sus condiciones internas de funcionamiento y de acondicionamiento, los cuales el mandante conoce como necesidades ineludibles, y que la normativa impone como condiciones mínimas de funcionamiento.

Las reglas de transformación debían representar la verdadera condición particular del colegio, aquello que lo haría diferente a todos los casos de estudio. Este es el problema conceptual mayor, puesto que supone sistemas de agrupación, zonificación y conexiones que aseguren el funcionamiento del programa bajo un concepto definido por el mandante, en este caso a través de un proyecto educativo. La enseñanza que impartiría el nuevo colegio sería coeducativa, es decir alumnos y alumnas compartirían parte de la infraestructura, no toda, contando con zonas de uso exclusivo y de uso compartido. A esta particularidad se sumaron las condiciones establecidas por los objetivos docentes y el currículum del colegio. Estas condiciones, que no cabe detallar en este texto, dieron como resultado el sistema de reglas de transformación que se encuentran resumidas en el esquema (fig. 3).

Las bases del concurso fueron redactadas de tal manera de encargar con precisión la enumeración de recintos, sus reglas de formación y sus reglas de transformación, abriendo el campo a lo más importante: los teoremas que cada concursante proponía como respuesta al encargo, dando forma al cálculo lógico propuesto como programa. De esta manera, los proyectos fueron comparables y la decisión del jurado se basó en la valoración de las formas, ideas y espacios que cada concursante propuso como solución. Como muestra del resultado se han hecho esquemas de algunas de las soluciones que muestran distintas opciones basadas en el mismo sistema de reglas (fig. 4). En ellas es posible apreciar que el cálculo lógico (fig. 3) aparece como estructura conceptual de los partidos generales, a pesar de tratarse de distintos teoremas, formas o soluciones. Esto demuestra la diversidad de posibilidades que abre un mismo programa arquitectónico. En síntesis, las bases de un concurso son una pieza clave para asegurar que la escena que se desarrolle sea la esperada, evitando la serie de contrariedades y tramas engorrosas que genera un concurso llamado sin un previo estudio, sin curso, o a la deriva. El instrumento para asegurar este cometido es el programa arquitectónico, que supera la mera lista de recintos. ARQ

\section{Bibliografía}

Fernández-Galiano, Luis. "Noticias de Córdoba: una mezquita lineal de Rem Koolhaas". Arquitectura Viva $N^{\circ}$ 77, Arquitectura Viva S.L., Madrid, 2001, pp. 88-95. / Le Corbusier. Une maison - un palais. Crès, París, 1928. / Morales, José Ricardo. "La arquitectura, técnica y arte". Arquitectónica. Parte segunda: Teoría. Ed. Universidad de Chile, Santiago, 1969./ Suárez, Isidro. "El programa arquitectural como entelequia del proyecto". Cuadernos de la Facultad. Documentos 5. Universidad del Norte, Facultad de Arquitectura, Antofagasta, 1985. / Zervos, Christian. “¿Quién construirá el Palacio de las Naciones?”. 3ZU Revista D’Architectura N 1 , ETSAB, Barcelona, 1993 (original 1927) pp. 62-65.
A diagram summarily represents this methodological approach to the work (Figure 1).

The study made it possible to set forth such specifications as the number of square meters per student that the new school was to have, and to relate this to the total area used for construction, as well as comparing this entire pattern with the case studies. The chart (Figure 2) shows one of the preliminary results of the study. It that clears that the enumeration of areas alone would have led to overestimating the spatial parameters for the school. The preliminary exercise provided an opportunity to reformulate and correct the potential error. Such exercises were carried out for different components of the project, such as the formal teaching areas, the yards and sports infrastructure, and other areas that might be defined by examining the features of the educational designs of the case studies.

The list of areas and their proper sizes consists of the enumeration and a part of the formational rules, since the technical requirements of the spaces are associated with their size, i.e., with the conditions under which their internal functioning and equipping must take place, which the commissioning entity identifies as irreducible needs, and which the parameters established must define as minimum conditions for functioning.

The transformational rules had to represent the particulars that make the school different from the case studies. This was the major conceptual problem, since it involved systems of classification, division of the total space into different zones, and connections that could guarantee that the design would function in terms of the concepts set forth by the commissioning entity (i.e., as an educational institution).

The new school was to be coeducational. Boys and girls were to share certain spaces, while other parts of the infrastructure were to be for exclusive use by one or another sex. In addition, there were conditions deriving from teaching objectives and curriculum. Though these conditions are not relevant here, the system of transformational rules to which they gave rise is summarized in the scheme (Figure 3).

The competition rules were written in such a way as to require a precise enumeration of areas, and their formational and transformational rules. This provided a framework for the most important part of the process, the theorems embodied in each competitor's proposal, which give form to the initial logical calculus. Thus, the proposals submitted could be compared, and the jury's decision was based on an evaluation of the forms, ideas and spaces that each competitor proposed as a solution to the challenges posed. As a sample of the results, diagrams were made of some of the solutions, showing different options based on the same system of rules (Figure 4). One may see that the logical calculus (Figure 3) appears as the conceptual structure of the game plans, despite the fact that different theorems, forms and solutions are involved in carrying them out. Thus, a diversity of possibilities is opened up by a single architectural program.

To summarize, the rules of a competition are a key to ensuring that the scene that unfolds is the one sought, and to preventing the various problems and complications that can arise when competitions lack prior study and direction. An architectural program that goes beyond a mere list of spaces provides the structure to accomplish this. ARQ

\section{Bibliography}

Fernández-Galiano, Luis. “Noticias de Córdoba: una mezquita lineal de Rem Koolhaas". Arquitectura Viva N ${ }^{\circ}$ 77, Arquitectura Viva S.L., Madrid, 2001, pp. 88-95. / Le Corbusier.Une maison - un palais. Crès, Paris, 1928. / Morales, José Ricardo. “La arquitectura, técnicay arte”. Arquitectónica. Parte segunda:Teoría. Ed.Universidad de Chile, Santiago, 1969. / Suárez, Isidro. "El programa arquitectural como entelequia del proyecto". Cuadernos de la Facultad. Documentos 5. Universidad del Norte, Facultad de Arquitectura, Antofagasta, 1985. / Zervos, Christian. “¿Quién construirá el Palacio de las Naciones?”. 3ZU Revista D'Architectura № 1 , ETSAB, Barcelona, 1993 (original 1927) pp. 62-65. 